\title{
BOŽSKÉ DVOJIČKY A ICH REFLEXIA V PREDSTAVÁCH SPOLOČNOSTI DOBY BRONZOVEJ ${ }^{1}$
}

\author{
M A R T I N E U M A N N
}

\begin{abstract}
Divine Twins and Their Reflection in the Bronze Age Ideology. This paper tackles the problem of Divine Twins in the Bronze Age ideology and its reflection in archaeological sources. Historical sources of Indo-European origin reflecting the social and ideological environment of the Bronze Age society are used as a starting point in the subsequent considerations. Attention is paid to the role of Divine Twins in the eschatological perception and their role in the living culture. Confrontation of various types of sources provides new insight on the interpretation of eschatology in the Bronze Age society.
\end{abstract}

Keywords: Europe, Bronze Age, Divine Twins, duality, eschatology.

\section{ÚVOD}

Existencia ambivalentných fenoménov v prirodzenom svete sa od počiatkov rozvoja kognitívnych funkcií človeka premietala do formovania ludských kultúr. Vlastné vnímanie polarity manifestoval človek rozličným spôsobom $\mathrm{v}$ rôznych sférach svojej každodennosti. $V$ prípade spoločnosti doby bronzovej, ktorá bude stát v centre nášho záujmu, sú tieto prejavy prísne limitované dochovanými materiálnymi pozostatkami a schopnostou rekonštruovat pôvodný kultúrny kód, ktorý v sebe niesli. Za účelom hlbšieho vniknutia do mysle človeka doby bronzovej sa preto často využíva čo najširšie spektrum dostupných prameňov, a to i nearcheologickej povahy. Analogický postup budeme aplikovat' i v tejto práci, kde si výskum prejavov duality môže vypomáhat najmä dochovanými písomnými prameňmi (z rôznych geografických oblastí), hoci len $s$ istou dávkou opatrnosti a s vedomím väčšieho či menšieho časového odstupu. Podmienkou takéhoto postupu je $\mathrm{v}$ tomto prípade predpoklad o zdielaní spoločného indoeurópskeho myšlienkového základu - kým pri použitých védskych a antických prameňov je to nepochybné, v prípade aliterárnych kultúr doby bronzovej v strednej Európe je to nanajvýš pravdepodobné (Anthony 2007; Rascovan a i. 2019, 301).

$\mathrm{V}$ tejto práci sme sa rozhodli prezentovat prístup, ktorý sa dnes môže zdat' trochu netradičným. V praxi bývajú archeologické fenomény interpretované pomocou poznatkov príbuzných vedných odborov (antropológia, etnológia, história). My sme zvolili opačný postup. Chápanie a prejavy duality zachytené predovšetkým $v$ historických prameňoch budeme cielene vyhl'adávat’ $\mathrm{v}$ archeologických prameňoch. Dúfame tak, že takýto prístup dovolí poodhalit aj d'alšie aspekty prejavov reflexie a manifestácie polarity, ktoré doposial' zostávajú skryté. Ako základné piliere pre dalšie úvahy budú využívané indické (védske) a antické písomné pramene, ktoré zdielajú spoločný indoeurópsky substrát.

\section{BRATIA DVOJIČKY}

Vdaka obdobiu svojho vzniku patria védske texty k najstarším písomne zachyteným náboženským textom $\mathrm{v}$ rámci indoeurópskeho priestoru (druhá polovica 2. tisícročia pred n. 1.). Nimi zachytená tradícia má však omnoho hlbšie korene (Vacek/Zbavitel $2020,9)$. Naznačuje to i o niekol'ko storočí mladšia grécka literárna tvorba, ktorá s nimi zdiela niektoré spoločné prvky. Zohladniac súčasné poznatky o období vetvenia jednotlivých indoeurópskych jazykov je tak možné klásț existenciu spoločného náboženského substrátu zachyteného v uvedených textoch minimálne do polovice 3. tisícročia pred n. 1 . (Blažek/Schwarz 2017, 164). Jedným z výrazných elementov rozoznatelných $\mathrm{v}$ oboch kultúrnych oblastiach je prítomnost' bratov dvojičiek $\mathrm{v}$ spoločenstve božských bytostí. $\mathrm{V}$ panteóne bohov spomínaných v Rigvéde (RV) sú nimi Ašvinovia či Nasatyovci, ktorých dopĺña ich sestra - bohyňa úsvitu Ušas. Ašvinovia vystupujú ako dvojica mladíkov, vždy bez konkretizácie ich vlastných mien. Ich pomenovanie Ašvinovia (Aśvinā) odkazuje na prepojenie s koňmi (aśva - kôň), čo je napokon reflektované aj v mnohých hymnoch Rigvédy. Bez zaujímavosti nie je ani skutočnost', že Ašvinovia bývajú označovaní ako mladí bohovia, niekedy dokonca ako najmladší (RV I. 117, 14; III. 58, 7; VI. 62, 4).

\footnotetext{
1 Príspevok vznikol v rámci riešenia projektu grantovej agentúry VEGA č. 1/0100/19.
} 
V antickej gréckej tradícii sa motív bratov dvojičiek vyskytuje taktiež. Najzretel'nejšie sa to preukazuje v prípade motívu božských dvojičiek, tzv. Dioskuroi, ktorý bol v antickej gréckej mytológii nebývalo rozšírený. Najznámejšou dvojicou sú nepochybne Kastor a Polydeukes spomínaní už v Homérovej Iliade (Iliada III. 235). Hoci boli známi pod spoločným menom ako Tyndareovci, mali rozdielnych otcov. Kým Kastora splodil s Lédou spartský král Tyndareus, otcom Polydeuka bol Zeus (Kerényi 1998, 82). Na rozdiel od védskej tradície neboli obaja bratia nesmrtelní, čo však ich vzájomné puto nijakým spôsobom neoslabovalo. $V$ gréckom myšlienkovom svete bolo narodenie dvojičiek vždy nerozlučne späté s predstavou o rozdielnom otcovstve. Častokrát však bolo počatie dvojičiek spojené s podozrením na cudzoložstvo matky. Zrkadlí sa to $\mathrm{v}$ príbehu dalších bratov dvojičiek - Zetha a Amfióna, údajných stavitelov tébskych hradieb, ktorých matka Antiopé, zvedená Diom, utiekla pred hnevom svojho otca do Sikyónu. Na úteku porodila v jaskyni dvoch synov, ktorých tu zanechala istému pastierovi na výchovu. Grécky antický svet však okrem Kastora a Polydeuka poznal celú plejádu d’alších dioskúrov. Hérakles mal svoju dvojičku Ifikla (Harris 1906, 5), v Messénii boli uctievaní bratia Idas a Lynkeus, ktorých splodil Poseidón s Aréné (Kerényi 1998, 84). Dvojicu bratov nezriedka

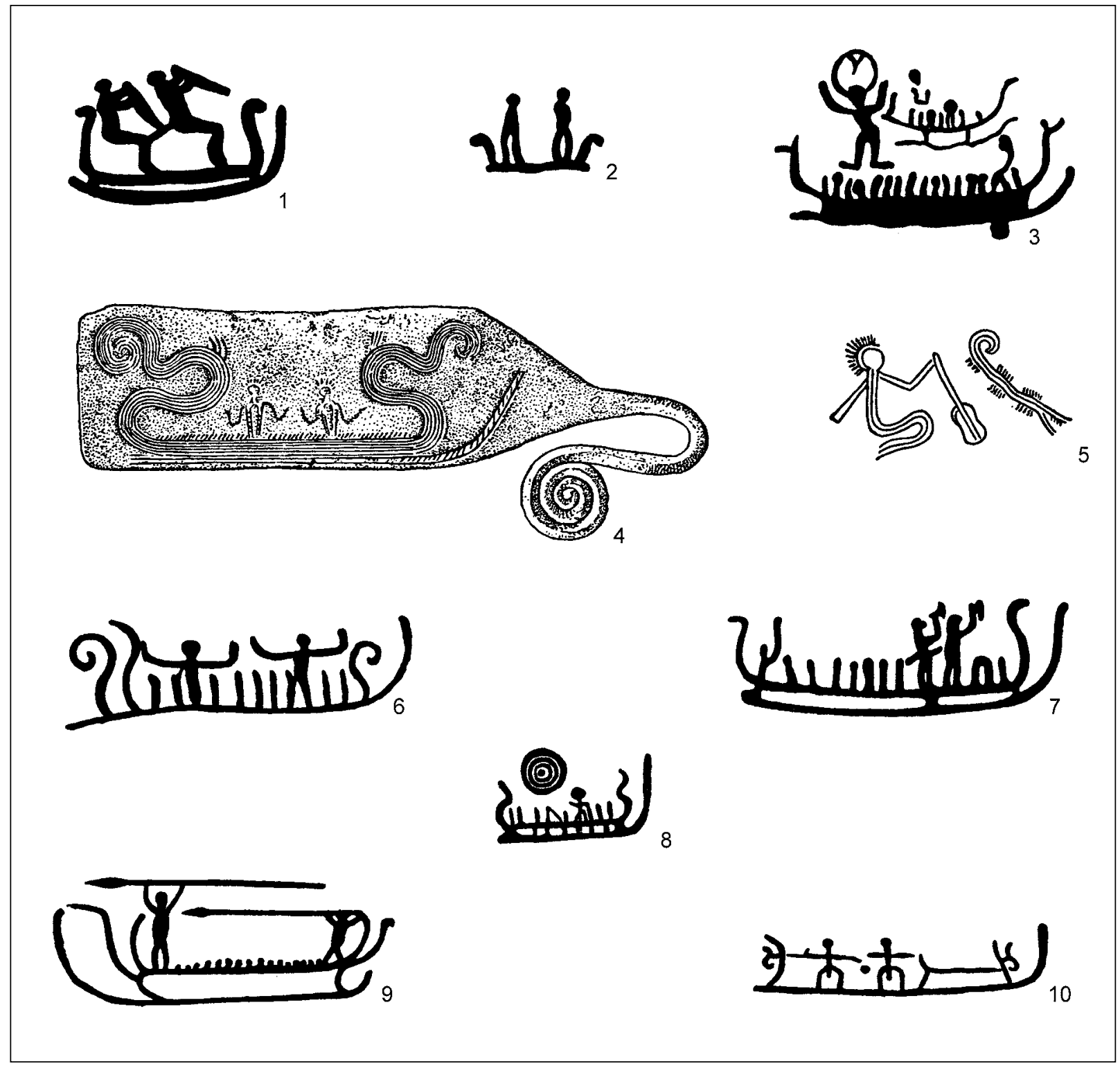

Obr. 1. Motívy dvojíc postáv z oblasti severnej Európy (podla Sprockhoff 1954, 80, 81). 1, 2, 7 - Bohuslän; 3 - Busgaard (Skjeberg); 4 - Voel (Gjern); 5 - okolie Brém; 6 - Evje (Tune); 8 - Gråbrekk (Trøndelag); 9 - Fiskeby (Östergötland); 10 - Begby (Borge). 
dopíňala sestra - v prípade Kastora a Polydeuka to bola Helena (Kerényi 1998, 33-37).

Významová náplň božských dvojičiek bola vo svojom základe pomerne nemenná, no napriek tomu sa zvykli časom zdôrazňovat' ich rozličné aspekty (Kristiansen 2011, 248; podrobnejšie pozri napr. Lehmann 1988; O’Brien 1997). Dokladá to spektrum nepočetných písomných prameňov, ktoré sa dobou vzniku či svojím obsahom vztahujú na európsku dobu bronzovú. Knajstarším možno zaradit Rigvédu z druhej polovice 2. tisícročia pred n. 1., o niečo mladšie sú pramene $\mathrm{z}$ antického Grécka. $\mathrm{V}$ nasledujúcom texte sa pokúsime načrtnút významovú náplň božských dvojičiek a pokúsime sa prezentovat’ jej manifestáciu v kultúrach staršej doby bronzovej.

\section{SOLÁRNA SYMBOLIKA}

Božské dvojičky sa dnes primárne spájajú so solárnou symbolikou. Toto prepojenie napokon potvrdzujú aj písomne zachytené tradície indoeurópskych spoločností. Vo védskych textoch vystupovali Ašvinovia v úlohe jazdcov na koňoch či na voze, ktorí dokázali obíst nebo i zem za vel'mi krátky čas (RV III. 58, 8). Ráno otvárali na svojom voze cestu pre svoju sestru - bohyňu úsvitu Ušas. Vd’aka ich každodennému pohybu po oblohe bola ,,jedna polovica dňa tmavá a druhá jasná", čo je zodpovedajúco personifikované $\mathrm{v}$ ich komplementárnych farbách (svetlá - tmavá; RV VI. 9, 1; Russel Coulter/Turner 2000, 77). Previazanie na solárnu symboliku možno nájst' aj u antických Dioskúrov. V gréckom prostredí boli Kastor a Polydeukes nazývaní aj ako euippoi (zdatní jazdci), leukippoi (biele kone) či leukopoloi (biele žriebätá; Nicoll 2008, 141; O’Brien 1997, 164). $\mathrm{V}$ tejto podobe sa objavujú v súvislosti s pohybom Slnka stelesneným v bohovi Héliovi. Ten bol spoločne so svojou sestrou Eos (Úsvit) vezený po oblohe vo voze tahanom dvoma koňmi s príznačnými menami - Lampas (Pochodeň) a Faethón (Žiariaci). Okrem konotácií s pohybom Slnka po oblohe a striedaním dňa a noci plnili aj d’alšie funkcie. Na tomto mieste sa bližšie budeme venovat' len jednej z nich, ktorá však býva častokrát prehliadaná - funkcii záchrancov v kontexte rôznych životných situácií.

\section{ZÁCHRANCOVIA NA MORI}

Pozícia božských dvojičiek vo funkcii záchrancov je doložená naprieč viacerými indoeurópskymi tradíciami. Ako dokladá jeden zo spevov Rigvédy, Ašvinovia boli známi svojou ochotou zasiahnut a pomôcť človeku v núdzi (RV I. 118, 3). Takúto udalosṫ zachytáva spev o záchrane Bhudžua. Bhudžu, ktorý bol na mori opustený svojím otcom Tugruom, bol zachránený Ašvinmi na ich lietajúcich vozoch tahaných koňmi a vrátený spät domov (RV I. 116, 3-5; 117, 14). Aj grécki Dioskúrovia vystupovali $\mathrm{v}$ antickej mytológii ako pomocníci na mori. Námorníci v núdzi vzývali božskú dvojicu, ktorá im vždy prišla na pomoc - nie však na vozoch, ale ako okrídlené bytosti, ktoré svojimi krídlami rozohnali búrku (Kerényi 1998, 87). Ako strážcovia správneho kurzu sú uvádzaní v jednom $\mathrm{z}$ hymnov pripisovaných Homérovi (Nicoll 2008, 154). Rovnako nebolo náhodou, že členmi Jásonovej družiny plaviacej sa na lodi Argo boli práve Dioskúrovia (Westmoreland 2006, 540).

V prípade príbehu o Bhudžuovi upozornil H. J. Walker na mierne odlišnú interpretáciu pasáže o záchrane Tugruovho syna. Pri porovnaní viacerých spevov Rigvédy vychádza najavo, že miesto, kde sa mal Bhudžu stratit, je raz označované ako more, inde ako atmosféra (RV I. 182, 6; VI. 62, 6). Ašvinovia po Bhudžua prichádzajú raz na lodiach, raz na letiacich vozoch. Opis miesta teda zostáva vel’mi neistý - nemenná je však predstava, že ide $\mathrm{o}$ „hlbočinu“ a miesto naplnené temnotou. H. J. Walker sa domnieva, že miesto, kde sa mal Bhudžu stratit,, nebolo more, ale skôr "kozmický oceán", ktorého vody sú prirovnávané $\mathrm{k}$ temnote. Rovnaké výrazy pre vodu a temnotu sú pritom použité v speve o počiatku vesmíru (RV I. 182, 6; Walker 2015, 62). Naznačuje to, že Bhudžu sa v okamžiku záchrany nachádzal $v$ neusporiadanom, chaotickom priestore, ktorý bol pre neho nepoznaný a nepríjemný. Domnievame sa, že situácia zachytená v speve predstavuje Ašvinov pri záchrane Bhudžua pred smrtou, resp. z chaotického a neusporiadaného stavu posmrtnej existencie (duše?). Napovedali by tomu i d’alšie indície, ktoré spomínajú božské dvojičky priamo v kontexte smrti a zmŕtvychvstania.

\section{ZÁCHRANCOVIA PRED SMRŤOU}

Grécka mytológia nie je v súvislosti s Dioskúrmi príliš bohatá na stopy preukazujúce spojenie medzi svetom živých a mŕtvych. Niekol'ko náznakov však predsa možno nájstt. Napriek svojmu božskému pôvodu bol jeden z Dioskúrov - Kastor - smrtelný (Kerényi 1996, 86, 119; Olmsted 2019, 239). Ked' bol smrtelne ranený oštepom, ktorý na neho vrhol Idas, prosil Polydeukes ich otca Dia, aby usmrtil aj jeho. Zeus však odmietol a navrhol mu život na Olympe medzi ostatnými bohmi alebo zdielanie osudu so svojím bratom. Polydeukes si vybral druhú možnost' - preto odvtedy obaja bratia prebývali jeden deň spoločne v podzemí a druhý deň spoločne na Olympe (Kerényi 1998, 86, 87). 
Explicitnú eschatologickú náplň božských dvojičiek však možno vysledovat v Rigvéde. V kontexte prinavracania života či životných síl sa božskí bratia Ašvinovia spomínajú v súvislosti so starcom Cyavanom a králom Kalim, ktorým prinavrátili ich mladý vek a silu (RV VII. 68, 6; 71, 5; RV X. 39, 8). Pôsobivý je i príbeh o záchrane Vandanu, ktorého démoni hodili do studne či dokonca pochovali (Maurer 1986, 146). Záchrana Vandanu je v Rigvéde opísaná ako „vytiahnutie skrytého pokladu z jamy“ (RV I. 116, 11), alebo ako „vytiahnutie čistého zlata, ktoré bolo pochované" (RV I. 117, 5). Na inom mieste

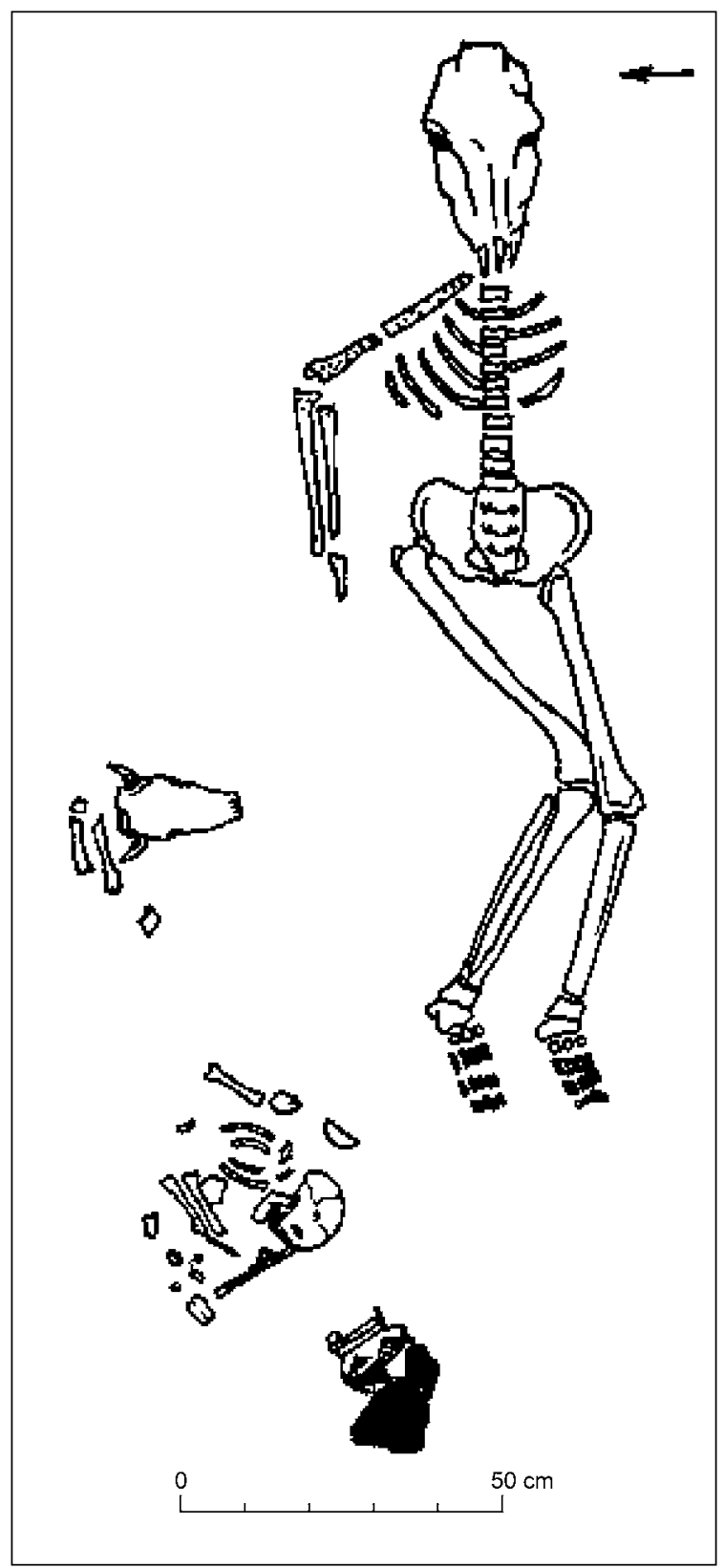

Obr. 2. Hrob jedinca s konskou lebkou z okolia ruskej Samary (podla Parpola 2015). sa zásah Ašvinov spája priamo s oživením Vandanu a jeho zázračným prinavrátením do sveta živých (RV I. 119, 7). Podobne bol Ašvinmi z úzkej jamy zachránený i mudrc Atri (RV I. 117, 3). Tým sa však rad oživených postáv nekončí. $V$ rovnakom kontexte sa spomína aj Visnapu, syn Visvaku či na tri kusy roztrhaný Syava, syn Vadhrmatiho (RV I. 117, 24; X. $65,12)$. Podobných „liečitel'ských“ či „oživovacích“ skutkov je v Rigvéde zaznamenaných mnoho (prehladne pozri Bhattacharji 1970, 237-239).

Zaujímavý príbeh podáva jedna z pasáží Šatapatha Bráhmany (SB), ktorá opisuje Ašvinov v kontexte konfliktu medzi mudrcom Dadhyancom Atharvanom a bohom Indrom. Indra totiž zakázal Dadhyancovi prezradif tajomstvo ako prinavrátif telu odtatú hlavu, a to pod trestom odt’atia hlavy. Ašvinovia však Dadhyanca požiadali, aby im toto tajomstvo prezradil. Dadhyanc súhlasil, no aby sa vyhol odtatiu hlavy bohom Indrom, nechal si ju odtat Ašvinmi. Tí mu ju okamžite nahradili konskou hlavou, ktorú mu následne odtal Indra. Bezprostredne nato však Ašvinovia, poznajúc tajomstvo prinavracania hláv $k$ telu, mudrcovi vrátili spät jeho ludskú hlavu (SB XIV. 1, 1, 18-24).

Naznačený kontext vysvetluje d’alšie meno používané pre Ašvinov vo védskych textoch - Nasatyovci. Sanskritský výraz nāsatya- sa odráža v gréckom mene pylského krála Nestora, ktorý bol skúseným vozatajom a jazdcom na koni. Obe vlastné mená majú spoločný pôvod $\mathrm{v}$ protoindoeurópskom koreni nes- $\mathrm{s}$ významom „,vrátit’ sa v poriadku domov“ (Bičovský 2017, 169). V archaickej gréčtine slovo nostos značilo návrat domov, no $\mathrm{v}$ zmysle návratu $\mathrm{z}$ temnoty a smrti (Lexicon 1884, 467). Záchrana Bhudžua z temnoty a chaosu „,kozmického oceánu“ či iných védskych hrdinov tým dostáva jasnejšie kontúry.

Prepojenie témy koní a voza s prechodom medzi životom a smrtou naznačuje i pohreb Patrokla opísaný v Iliade. Na jeho pohrebnú hranicu boli položené štyri kone, ktoré boli spolu s ním aj spálené. Patroklov majetok bol následne delený na závodoch vozov (verše 171, 172). Nestor spomína podobný pohrebný závod, kde mal byt porazený synmi Aktora - jeden z bratov (išlo o dvojičky!) držal opraty, zatial' čo druhý sa oháňal bičom (Parpola 2015, 118). Náznaky praktizovania takýchto funerálnych závodov nepriamo naznačuje závod bohov spomínaný v Aitareya-Brāhmane (IV, 7-9). Pozoruhodné je, že voz Ašvinov tu nebol zapriahnutý koňmi, ale oslami (Haug 1922, 185). Nie je tiež bez zaujímavosti, že osly sú vo védskej tradícii spájané nielen s plodnostou, no i so smrtou (Parpola/Janhunen 2011, 71). 


\section{DISKUSIA}

Idea božských bratov - dvojičiek bola v indoeurópskej mytológii hlboko zakorenená a rozšírená naprieč mnohými kultúrami eurázijského kontinentu (Parpola 2015, 109). V aliterárnych spoločnostiach staršej doby bronzovej v strednej Európe je však náročné s istotou identifikovat' kultúrne prejavy tejto ideológie. Istú pomoc poskytuje len analýza archeologických prameňov konfrontovaná s výsledkami indoeurópskej religionistiky. Pri opatrnom a kritickom postupe je tak možné objavit náznaky príslušnosti stredoeurópskych starobronzových kultúr k spoločnému indoeurópskemu myšlienkovému substrátu. Najkomplexnejšiu informáciu o myšlienkovom svete vtedajších spoločností poskytujú predovšetkým pohrebiská a analýzy hrobových celkov. Pozorný pohlad na obsah hrobovej výbavy na pohrebiskách zo staršej doby bronzovej na Slovensku či na celkový kontext rituálne uloženého jedinca (napr. v sídliskových objektoch) dokáže ponúknut indície poukazujúce na aktívne vnímanie (a využívanie) významovej náplne bipolárnej symboliky v živej spoločnosti. Hrobové prílohy vo forme rybích kostí, stavcov, korytnačích pancierov či riečnych korýtok tak nemusia byt̉ len výhradne potravinovou prílohou, no intencionálnym odkazom na ",kozmický oceán“, v ktorom bolo možné očakávat' záchranu od božských dvojičiek. Príkladov dokladajúcich takúto prax je v literatúre mnoho (podrobne Jelínek 2016). Korytnačka všeobecne predstavuje symbol nesmrtelnosti (Heinz-Mohr 1981, 254). V prípade lastúr sa predpokladá ich súvis s pohrebnými obradmi, kde mali slúžit ako symbol vzkriesenia (Jelinek 2015, 62, 63). Neprekvapuje preto ich výskyt $\mathrm{v}$ sídliskových objektoch (dokonca s dvojicami ludských skeletov!), ktoré boli sekundárne využité ako hroby (Jelínek 2016). P. Jelínek poukázal na fakt, že mušlami boli posmrtne vybavovaní najmä tí jedinci, ktorým bolo odopreté pochovanie na regulárnych pohrebiskách (Jelínek 2015, 65). Účelom príloh akvatického charakteru tak pravdepodobne bolo zaručit záchranu týchto nebožtíkov - takáto predstava nie je $\mathrm{v}$ protiklade s myšlienkou o existencii abstraktného ",kozmického oceánu“ - transcendentálneho neusporiadaného priestoru, kde nebolo dlhšie zotrvanie žiaduce. Záchranu z "morského" chaosu prinášali božské dvojičky. Predstava o božských dvojičkách ako moreplavcoch bola v dobe bronzovej v Európe jednoznačne rozšírená, o čom svedčia ikonografické zobrazenia z oblasti Škandinávie a severného Nemecka. Na tomto mieste len upozorníme na opakujúci sa motív dvojice postáv na zobrazených plavidlách $\mathrm{v}$ rôznom štylistickom prevedení (podrobnejšie Sprockhoff 1954, 79-81). Práve kvôli zobrazeniu "dvojičiek" na lodiach uvažoval E. Sprockhoff o ich funkcii ako ochrancov moreplavcov či o pomocníkoch v núdzi na mori (obr. 1: 1-4, 6, 7, 9, 10; Nilsson 1992, 408; Sprockhoff 1954, 88). V niektorých prípadoch je dokonca evidentné ich prepojenie so slnečnou symbolikou (obr. 1: 3-5; na britve z lokality Voel majú postavy okolo hlavy „svätožiaru“, rovnako tiež postava „veslára“ na britve z okolia Brém; o svätožiare možno uvažovat i v prípade postavy z Busgaardu; dalšie príklady uvádza Sprockhoff 1954, 80). J. Brønsted označil takéto postavy rovno za slnečných bohov (Brønsted 1938, 100). Napriek tomu sa domnievame, že uvedené interpretácie treba doplnit - božské dvojičky boli nielen pomocníkmi v núdzi na mori, no v prenesenom zmysle aj záchrancami plaviacich sa na už spomínanom „kozmickom oceáne“.

Aktívna participácia na predstavách indoeurópskeho myšlienkového komplexu mohla byṫ reflektovaná aj v d’alšom fenoméne-sekundárnom otváraní hrobov (Bátora 2018, 269). Motív záchrany mŕtvych védskych hrdinov prezentovaný v Rigvéde ako „,vytiahnutie skrytého pokladu z jamy“ alebo „vytiahnutie čistého zlata, ktoré bolo pochované", sa mohol $\mathrm{v}$ stredoeurópskom priestore premietnut práve do spomínaného javu. Rituál otvárania hrobov v krat-

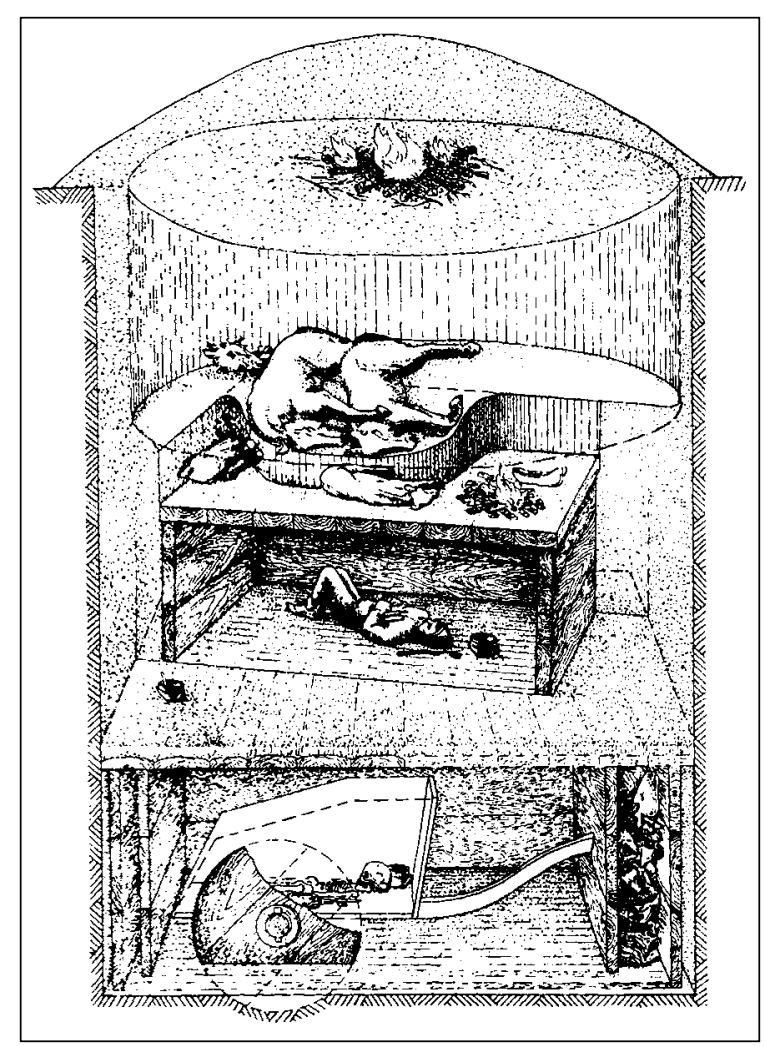

Obr. 3. Hrob z juhouralskej Sintašty, v ktorom bol bojovník pochovaný spoločne s jazdcom, vozom a párom koní (podla Parpola 2015). 
šom či dlhšom časovom intervale po pochovaní nebožtíka mohol týmto spôsobom sledovat reiteráciu mytologických dejov (s cielom "oživenia“ jedinca pre večný život?). Dodnes nediskutovanou otázkou je absencia pendantu sekundárne otvorených hrobov v súbore sídliskových jám využitých sekundárne ako hrob. Bola takto pochovaným jedincom odopretá možnost’ byt๋ rituálne „vzkrieseni“? Táto úloha mohla byt’ ponechaná na "božské dvojičky“, čomu by nasvedčovala prítomnost' akvatoriálnych nálezov v kontexte hrobov v sídliskových jamách.

Praktika odtínania hlavy a jej nahradenie konskou hlavou opísaná v Rigvéde v slovenskom prostredí síce nie je doložená, no v inom svetle sa môžu javit pohreby ludských jedincov s priloženými lebkami koní, somárov, či oslov (obr. 2; porovnaj $\mathrm{s}$ diskutovaným hrobom z okolia Samary; Parpola 2015, 123). Na Slovensku patria hroby z obdobia staršej a strednej doby bronzovej s parciálnym spolupochovaním koňa skôr k zriedkavostiam. K sporadickým príkladom sa zaraduje sídliskový objekt mad’arovskej kultúry z Nitry, v ktorom ležali 2 detskí jedinci spoločne s lebkou žriebäta (Markovál Samuel 2008, 69). K nim pravdepodobne patrí i hrob s (bližšie nešpecifikovanými) konskými kostami odokrytý vo Vrábloch (Bátora 2018, 323). Nemožno vylúčit možnost', že kôň mal v tomto kontexte plnit funkciu psychopompa - sprievodcu duše na druhý svet, resp. na nebesia (Kuzmina 2007, 193). Rovnaká náplň je pripisovaná aj božským dvojičkám (Ašvinom), ktoré sú bežne asociované s koňmi (sanskrtské $a s ́ v a=$ kôň, v Grécku boli Dioskúrovia známi aj pod menami spájanými s koňmi - euippoi, leukippoi či leukopoloi).

Bipolárny pohlad reprezentovaný $\mathrm{v}$ mytologickom svete božskými dvojičkami sa zodpovedajúcou mierou odrážal aj pozemskom živote (Kristiansen 2001, 93). Preukázatel'né je to v kultúrne blízkom gréckom antickom svete $s$ hierarchicky štruktúrovanou spoločnostou. Dominantného krála-kňaza (wanax) dopíňal král-bojovník (lawagetas) - kým wanax plnil predovšetkým náboženské funkcie, lawagetas nachádzal uplatnenie predovšetkým v organizovaní vojska, v záležitostiach vojny a boja (Kristiansen/Larsson 2005, 280; Lynn Budin 2004, 182-184; Neumann 2019, 109, 110). Dvojicu vodcov zachytil Homér v opise danajských vojsk tiahnucich k Tróji - na čele Fókov stáli Schedios s Epistrofom (Iliada II, 517-526), krétskym vojakom velil Ídomeneus a Mérion (Iliada II, 6549-652), na čele vojska z ostrova Nísýra stáli Thessalovi synovia Feidippos a Antifos (Iliada II, 678), Trikčanov a Ithómčanov viedli bratia Macháón s Podaleiriom (Iliada II, 732) a na čele vojska z Argissy stál Polypoités a Leonteus (Iliada II, 738-747). Binárna štruktúra však bola vštepená aj do nižších úrovní vojska. Najzretelnejšie sa to prejavovalo pri vedení bojových vozov Achájci totiž nebojovali priamo z voza, no bojovník z neho musel pred bojom zostúpit. Jeho spoločník ho čakal na voze a v prípade nebezpečenstva ho odviezol z bojového pola (tým sa opät ukážkovo napíňal význam slova nostos - bezpečného návratu $z$ nebezpečenstva smrti). Úzke previazanie oboch bojovníkov sa v niektorých oblastiach premietlo aj $\mathrm{v}$ pohrebnom ríte. Známy je napríklad hrob bojovníka spolu s jazdcom, vozom, párom koní a d’alšou výbavou z juhouralskej Sintašty (obr. 3; Parpola 2015, 60). Analógie v strednej Európe zatial' absentujú. Výnimočný hrob z nemeckého Leubingenu s dvojicou pochovaných jedincov (aj s pármi rovnakých predmetov v pohrebnej výbave) má s najväčšou pravdepodobnostou iné ideologické pozadie (Müller 2001, 289; Vandkilde 2007, 106).

Hoci prítomnost' predstáv o božských dvojičkách a s nimi spojených myšlienkových konceptov nie je možné $\mathrm{v}$ stredoeurópskom priestore prostredníctvom archeologických prameňov priamo a jednoznačne dokázat', s pomocou prameňov nearcheologickej povahy je možné minimálne odokrývat náznaky o ich existencii v období doby bronzovej. Konfrontácia s písomnými prameňmi naznačuje, že v myšlienkovom svete vtedajšej spoločnosti existovala vyhranená predstava o funkcii božských dvojičiek, ktorá ideovo nadväzovala na védskych Ašvinov či antických Dioskúrov. Jej prejavy je pri súčasnom stave poznania možné predpokladat a najlepšie rekonštruovat predovšetkým v prostredí eschatologických predstáv. Ambíciou d’alšieho výskumu musí byt' preto potvrdit', resp. vyvrátit tieto závery a identifikovat ich prejavy aj v d’alších sférach každodenného života spoločnosti doby bronzovej. 


\section{LITERATÚRA}

Anthony 2007 - D. W. Anthony: The Horse, the Wheel and Language. How Bronze-Age Riders from the Eurasian Steppes Shaped the Modern World. Princeton - Oxford 2007.

Bátora 2018 - J. Bátora: Slovensko v staršej dobe bronzovej. Bratislava 2018.

Bhattacharji 1970 - S. Bhattacharji: The Indian Theogony. Comparative Study of Indian Mythology from the Vedas to the Puranas. Cambridge 1970.

Bičovský 2017 - J. Bičovský: Praindoevropština II. Dodatky. Praha 2017.

Blažek/Schwarz 2017 - V. Blažek/M. Schwarz: Raní Indoevropané v Centrální Asii a v Čině. Kulturní vztahy v zrcadle jazyka. Praha 2017.

Brønsted 1938 - J. Brønsted: Bronzealderens soldyrkelse. Fra Nationalmuseets Arbejdsmark, 1938, 81-100.

Harris 1906 - J. R. Harris: The Cult of the Heavenly Twins. Cambridge 1906.

Haug 1922 - M. Haug: Aitareya Brahmana of the Rigveda. Vol. 1. Allahabad 1922.

Heinz-Mohr 1981 - G. Heinz-Mohr: Lexikon der Symbole. Bilder und Zeichen der christlichen Kunst. Düsseldorf Köln 1981.

Jelínek 2015 - P. Jelínek: Sladkovodné lastúrniky a ich symbolika v mad’arovskej kultúre. In: J. Bartík (ed.): Zborník na pamiatku Jozefa Paulíka. Štúdie. Zborník SNM. Archeológia. Supplementum 9. Bratislava 2015, 53-76.

Jelínek 2016 - P. Jelínek: Objekty s dvojicami ludských skeletov na sídliskách staršej a strednej doby bronzovej na Slovensku. Zborník SNM 110. Archeológia 26, 2016, 27-35.

Kerényi 1996 - K. Kerényi: Mytologie Řeků I. Praha 1996.

Kerényi 1998 - K. Kerényi: Mytologie Řeků II. Praha 1998.

Kristiansen 2001 - K. Kristiansen: Rulers and Warriors. Symbolic Transmission and Social Transformation in Bronze Age Europe. In: J. Haas (ed.): From Leaders to Rulers. New York 2001, 85-104.

Kristiansen 2011 - K. Kristiansen: Bridging India and Scandinavia: Institutional Transmission and Elite Conquest during the Bronze Age. In: T. C. Wilkinson/S. Sherratt/ J. Bennet (eds.): Interweaving Worlds. Systemic Interactions in Eurasia, $7^{\text {th }}$ to $1^{\text {st }}$ Millennia BC. Oxford 2011.

Kristiansen/Larsson 2005 - K. Kristiansen/T. B. Larsson: The Rise of Bronze Age Society. Travels, Transmission and Transformations. Cambridge 2005.

Kuzmina 2007 - E. E. Kuzmina: The Origin of the IndoIranians. Leiden - Boston 2007.

Lehmann 1988 - W. P. Lehmann: 'The Divine Twins' or 'The Twins ... Divine?' In: M. A. Jazayety/W. Winter (eds.): Language and Cultures. Studies in Honour of Edgar C. Polomé. New York 1988, 373-380.
Lexicon 1884 - A Lexicon Abridged from Liddel and Scott's Greek-English Lexicon. Boston 1884.

Lynn Budin 2004 - S. Lynn Budin: The Ancient Greeks. New Perspectives. Santa Barbara 2004.

Marková/Samuel 2008 - K. Marková/M. Samuel: Nálezy zo staršej a začiatku strednej doby bronzovej z Ponitrianskej galérie v Nitre. Študijné zvesti AÚ SAV 43, 2008, 63-93.

Maurer 1986 - W. H. Maurer: Pinnacles of India's Past. Selections from Rgveda. Amsterdam - Philadelphia 1986.

Müller 2001 - R. Müller: Leubingen. In: H. Beck/D. Geuenich/H. Steuer (Hrsg.): Reallexikon der Germanischen Altertumskunde. Band 18. Berlin - New York 2001, 288-289.

Neumann 2019 - M. Neumann: Pohlad na prelom staršej a strednej doby bronzovej v strednom Podunajsku. In: B. Kovár/M. Ruttkay (ed.): Kolaps očami archeológie. Nitra 2019, 103-114.

Nicoll 2008 - A. Nicoll: Chapman's Homeric Hymns and Other Homerica. Bollingen Series 41. Princeton - Oxford 2008.

Nilsson 1992 - M. P. Nilsson: Geschichte der griechischen Religion. Erster Band. München 1992.

O'Brien 1997 - S. O'Brien: Divine Twins. In: J. P. Mallory/ D. Q. Adams (eds.): Encyclopedia of Indo-European Culture. London - Chicago 1997.

Olmsted 2019 - G. Olmsted: The Gods of the Celts and the Indo-Europeans. Clynchdale 2019.

Parpola 2015 - A. Parpola: The Roots of Hinduism. The Early Aryans and the Indus Civilization. Oxford 2015.

Parpola/Janhunen 2011 - A. Parpola/J. Janhunen: On the Asiatic Wild Asses and Their Vernacular Names. In: T. Osada/H. Endo (eds.): Linguistics, Archaeology and the Human Past. Kyoto 2011.

Rascovan a i. 2019 - N. Rascovan/K.-G. Sjögren/ K. Kristiansen/R. Nielsen/E. Willerslev/C. Desnues/ S. Rasmussen: Emergence and Spread of Basal Lineages of Yersinia Pestis during the Neolithic Decline. Cell 176, 2019, 295-305.

Russel Coulter/Turner 2000 - C. Russel Coulter/P. Turner: Encyclopedia of Ancient Deities. Chicago - London 2000.

Sprockhoff 1954 - E. Sprockhoff: Nordische Bronzezeit und frühes Griechentum. Jahrbuch des Römisch-Germanischen Zentralmuseums Mainz 1, 1954, 28-110.

Vacek/Zbavitel 2020 - J. Vacek/D. Zbavitel: Základní texty východních náboženství 1. Hinduismus. Praha 2020.

Vandkilde 2007 - H. Vandkilde: Culture and Change in Central European Prehistory. $6^{\text {th }}$ to $1^{\text {st }}$ Millennium BC. Aarhus 2007.

Walker 2015 - H. J. Walker: The Twin Gods. The Dioskouroi in Mythologies of the Ancient World. London - New York 2015.

Westmoreland 2006 - P. L. Westmoreland: Ancient Greek Beliefs. San Ysidro 2006.

Mgr. \& Mgr. Martin Neumann, PhD.

Katedra archeológie

Filozofická fakulta UK v Bratislave

Gondova 2

SK - 81102 Bratislava

martin.neumann@uniba.sk 


\title{
Divine Twins and Their Reflexion in the Bronze Age Ideology
}

\author{
Martin Neumann
}

SUMMARY

The idea of Divine Twins was deeply rooted in the IndoEuropean mythologies across the whole Eurasia. However, it is rather difficult to uncover phenomena connected to this concept throughout the Bronze Age ideologies. Very helpful is confrontation of the archaeological sources with old written texts of Indian and Greek origin, which both preserve the same cultural background (Vedas, Homeric epics). Here, Divine Twins emerge as Aśvins (in Sanskrit aśva $=$ horse) or Dioskuroi (other Greek names are connected to horses-euippoi, leukippoi or leukopoloi). They are presented as young Gods, able charioteers and saviours from death. Their healing and rescuing deeds are at length described in Rigveda. Many Vedic heroes were rescued from death or revived by them. Of exceeding importance is the tale about Bhudju's rescue from the 'ocean' which epitomizes darkness or primordial cosmic chaos. Twin Gods as 'seafarers' were capable of saving Bhudju from this 'cosmic chaos' and bring him back to his father. It is probable that the 'sea' or 'ocean' represents a chaotic after-life world - place, where no one would like to stay. Twin Gods are the saviours who are able to provide help in this situation. This mythologem was probably reflected

Fig. 1. Motives with two figures from the northern Europe (after Sprockhoff 1954, 80, 81). 1, 2, 7 - Bohuslän, 3 - Busgaard (Skjeberg), 4 - Voel (Gjern), 5 - surroundings of Bremen, 6 - Evje (Tune), 8 - Gråbrekk (Trøndelag), 9 Fiskeby (Östergötland), 10 - Begby (Borge). in the eschatology of the European Bronze Age societies. Despite the absence of any domestic written sources it is possible to identify certain elements testifying for the comprehensive usage of Divine Twins' concept in Europe. Shells, turtle shells, fish vertebrae of bones found in settlement pits along with human skeletons (often in pairs) could have symbolized the transcendent chaotic 'ocean' from where a deceased should have been saved. On the other hand, secondarily opened graves could have reflected the rituals of 'resurrection' as described in Rigvedic hymns (reviving of Vandana, Atri, Visnapu, Syava). In this case 'resurrection' had been realized by the society (thus ritually substituting the intervention of Divine Twins), while in the case of settlement pits with buried humans salvage had been awaited directly from Twin Gods (as suggested by the presence of aquatorial artifacts). Concept of Divine Twins was reflected in the Bronze Age social structure too. Homeric epics indicate dual leading of social units (kingpriest and king-warrior). However, only the future research will provide more structured insight on adoption of the Divine Twins' concept in the social ideology.

Fig. 2. Human burial with horse skull from the surroundings of Samara, Russia (after Parpola 2015).

Fig. 3. Grave from Sintašta (Southern Ural). A warrior was buried along with his charioteer, chariot and team of horses (after Parpola 2015). 